\title{
Recommendations for screening, monitoring, prevention, and prophylaxis of infections in adult and pediatric patients receiving CAR T-cell therapy: a position paper
}

\author{
Ibai Los-Arcos ${ }^{1,2}$ - Gloria lacoboni ${ }^{3,4}$ - Manuela Aguilar-Guisado ${ }^{5}$ Laia Alsina-Manrique ${ }^{6}$. Cristina Díaz de Heredia ${ }^{7}$. \\ Claudia Fortuny-Guasch ${ }^{8}$. Irene García-Cadenas ${ }^{9}$. Carolina García-Vidal ${ }^{10}$ - Marta González-Vicent ${ }^{11}$. \\ Rafael Hernani ${ }^{12} \cdot$ Mi Kwon $^{13} \cdot$ Marina Machado $^{14}$ - Xavier Martínez-Gómez ${ }^{15}$. Valentín Ortiz Maldonado ${ }^{16,17}$. \\ Carolina Pinto $\mathrm{Pla}^{18}$. José Luis Piñana ${ }^{19} \cdot$ Virginia Pomar $^{20}$. Juan Luis Reguera-Ortega ${ }^{21}$. Miguel Salavert ${ }^{22}$. \\ Pere Soler-Palacín ${ }^{23}$ - Lourdes Vázquez-López ${ }^{24} \cdot$ Pere Barba $^{3,4}$ - $\cdot$ Isabel Ruiz-Camps ${ }^{1,2}$
}

Received: 18 June 2020 / Accepted: 29 August 2020 / Published online: 26 September 2020

(c) Springer-Verlag GmbH Germany, part of Springer Nature 2020

\begin{abstract}
Chimeric antigen receptor (CAR) T-cell therapy is one of the most promising emerging treatments for B-cell malignancies. Recently, two CAR T-cell products (axicabtagene ciloleucel and tisagenlecleucel) have been approved for patients with aggressive B-cell lymphoma and acute lymphoblastic leukemia; many other CAR-T constructs are in research for both hematological and non-hematological diseases. Most of the patients receiving CAR-T therapy will develop fever at some point after infusion, mainly due to cytokine release syndrome (CRS). The onset of CRS is often indistinguishable from an infection, which makes management of these patients challenging. In addition to the lymphodepleting chemotherapy and CAR T cells, the treatment of complications with corticosteroids and/or tocilizumab increases the risk of infection in these patients. Data regarding incidence, risk factors and prevention of infections in patients receiving CAR-T cell therapy are scarce. To assist in patient care, a multidisciplinary team from hospitals designated by the Spanish Ministry of Health to perform CAR-T therapy prepared these recommendations. We reviewed the literature on the incidence, risk factors, and management of infections in adult and pediatric patients receiving CAR-T cell treatment. Recommendations cover different areas: monitoring and treatment of hypogammaglobulinemia, prevention, prophylaxis, and management of bacterial, viral, and fungal infections as well as vaccination prior and after CAR-T cell therapy.
\end{abstract}

Keywords Chimeric antigen receptor - Diffuse large B-cell lymphoma - B-cell acute lymphoblastic leukemia Bacterial infections · Viral infections · Fungal infections

\section{Introduction}

Chimeric antigen receptor (CAR) T-cell therapy is one of the most promising emerging treatments for hematologic malignancies [1,2]. Although there are several therapeutic targets under development, CD19 is the most widely used antigen for the treatment of B-cell malignancies. Recently, two CAR T products have been approved for the treatment

Members of the Infection Prevention in CAR T-cells Study Group are listed in acknowledgements.

Pere Barba

pbarba@vhio.net

Extended author information available on the last page of the article of lymphoid malignancies, axicabtagene ciloleucel (axi-cel) or Yescarta ${ }^{\circledR}$ (Gilead Inc., USA) for the treatment of diffuse large B-cell lymphoma (DLBCL) and primary mediastinal B-cell lymphoma (PMBCL), and tisagenlecleucel (tisa-cel) or Kymriah ${ }^{\circledR}$ (Novartis Inc., Basel, Switzerland) for the treatment of DLBCL and B-cell acute lymphoblastic leukemia (B-ALL).

Most of the patients receiving CAR T therapy will develop fever after infusion [3], mainly due to cytokine release syndrome (CRS), a systemic inflammatory condition mediated by CAR T-cells. This syndrome is often indistinguishable from an infection as it usually includes tachycardia, tachypnea and hypotension [4]. CRS is produced by endothelial activation and overproduction of inflammatory cytokines such as interferon $\gamma$ (IFN- $\gamma$ ), interleukin 6 (IL-6) 
and tumor necrosis alpha (TNF- $\alpha$ ) [5]. Increased plasma levels of these cytokines have also been observed in sepsis [6]. Some studies have looked into the cytokine results in both CRS and infection trying to find a different biomarker profile. One of these studies did not find any differences in the cytokine profile of these two groups of patients [7]. However, another study was able to develop a prediction model including three cytokines (IL-8, IL- $1 \beta$ and IFN- $\gamma$ ) to detect life-threatening infections [8]. In any case, more research is needed to identify specific biomarkers differentiating the two clinical settings.

Since only a limited number of patients have been treated with CAR T-cell therapies, there are scarce data on incidence, risk factors and preventive strategies $[8,9]$ in these patients. We present herein recommendations on the management of infections for patients receiving CAR T cells.

\section{Methodology}

A multidisciplinary team from the hospitals designated by the Spanish Ministry of Health to deliver CAR T-cell therapy contributed to this set of recommendations for prevention and management of infections. To implement clinical decisions, these recommendations should always be considered together with the underlying disease, previous treatments and local epidemiology.

The preparation and writing of this manuscript involved hematologists, infectious diseases specialists and pediatricians. We performed a systematic literature search in PubMed, using the search filters "CAR T AND infection", "CAR T AND follow-up", "CAR T AND prophylaxis", "CAR T AND hypogammaglobulinemia" and "CAR T AND vaccines". The final document was reviewed and approved by all authors. Table 1 is a summary of the most important recommendations of this document.

\section{Incidence and risk factors}

\section{Incidence}

Data regarding the incidence of infections in these patients are scarce, and this may vary depending on the underlying disease and the CAR T construct. The reported incidence of any infection in patients treated with tisa-cel for B-cell precursor ALL [9] and DLBCL is $65 \%$ and $54 \%$, respectively. Serious infections (grade 3 or higher) occurred in $44 \%$ and $32 \%$ of ALL and DLBCL patients, respectively, most of them occurring within the first 8 weeks after CAR T-cell infusion. Regarding axi-cel, $35 \%$ and $38 \%$ of patients with relapsed/refractory DLBCL included in the ZUMA-1 trial developed febrile neutropenia and infections, respectively [10]; $25 \%$ of these infections were grade 3 or higher.
Most patients had an infection without microbiological isolation, followed by bacterial and viral infections, mostly with respiratory tract involvement. Logue et al. described a similar incidence of infections, $37 \%$ in the first 30 days, being Clostridioides difficile colitis the most frequent (14\% of all patients) [11]. Recently, Wudhikarn et al. reported in patients with DLBCL a cumulative incidence of $63 \%$ of infections at 1 year [12].

Finally, Cordeiro et al. [13] reported an infection density of 0.55 infections/100 days at risk (2.08/patient year) within the first 90 days after CAR T-cell infusion in adult patients. Eighty percent of them were treated in the outpatient setting. Twenty-four percent of these events had a microbiological etiology, mainly bacterial (60\%), viral (31\%) (mostly respiratory viruses) and fungal (9\%) infections. Moreover, infection was the main cause of non-relapse mortality $(8 / 12$ cases, 66.7\%) in DLBCL patients treated with axi-cel in the standard-of-care setting [14].

\section{Risk factors}

Patient-, disease- and construct-related factors as well as treatment-related variables can increase the risk of infection $[7,12,15]$. Age has been identified as a risk factor for developing CRS and neurological events after CAR T-cell therapy [16], but it has not been clearly associated with an increased risk of infection. Baseline disease (being higher in ALL than in DLBCL), type and number of previous antitumor regimens have also been identified as potential risk factors for the development of infections. The dose of CAR T-lymphocytes [15], as well as type and intensity of lymphodepleting chemotherapy can also contribute to the development of infections after therapy [15]. Neutropenia, which has been described in up to $80 \%$ of the patients within the first month after infusion [17] can also increase the risk of infection in these patients, especially in those with long-term persisting cytopenias $[13,17,18]$.

CRS itself through endothelial damage and its treatment with tocilizumab and/or corticosteroids can favor and/or complicate some infections [7, 15]. Tocilizumab has been associated with increased risk of infection in patients with rheumatoid arthritis [19]. In patients receiving CAR T cells, its use has also been associated with a higher risk of infection. Since tocilizumab is used in most cases of severe CRS it is difficult to differentiate between CRS itself and its treatment as the direct cause of infections. In patients with mild CRS (grade 1) the use of tocilizumab was not associated with increased risk of infection in a recent study [20]. In some cases, anakinra (IL-1R inhibitor) has been used for the treatment of CRS and neurotoxicity [21]; this drug could also potentially increase the risk of infection [22, 23], but clinical experience in these patients is scarce. 


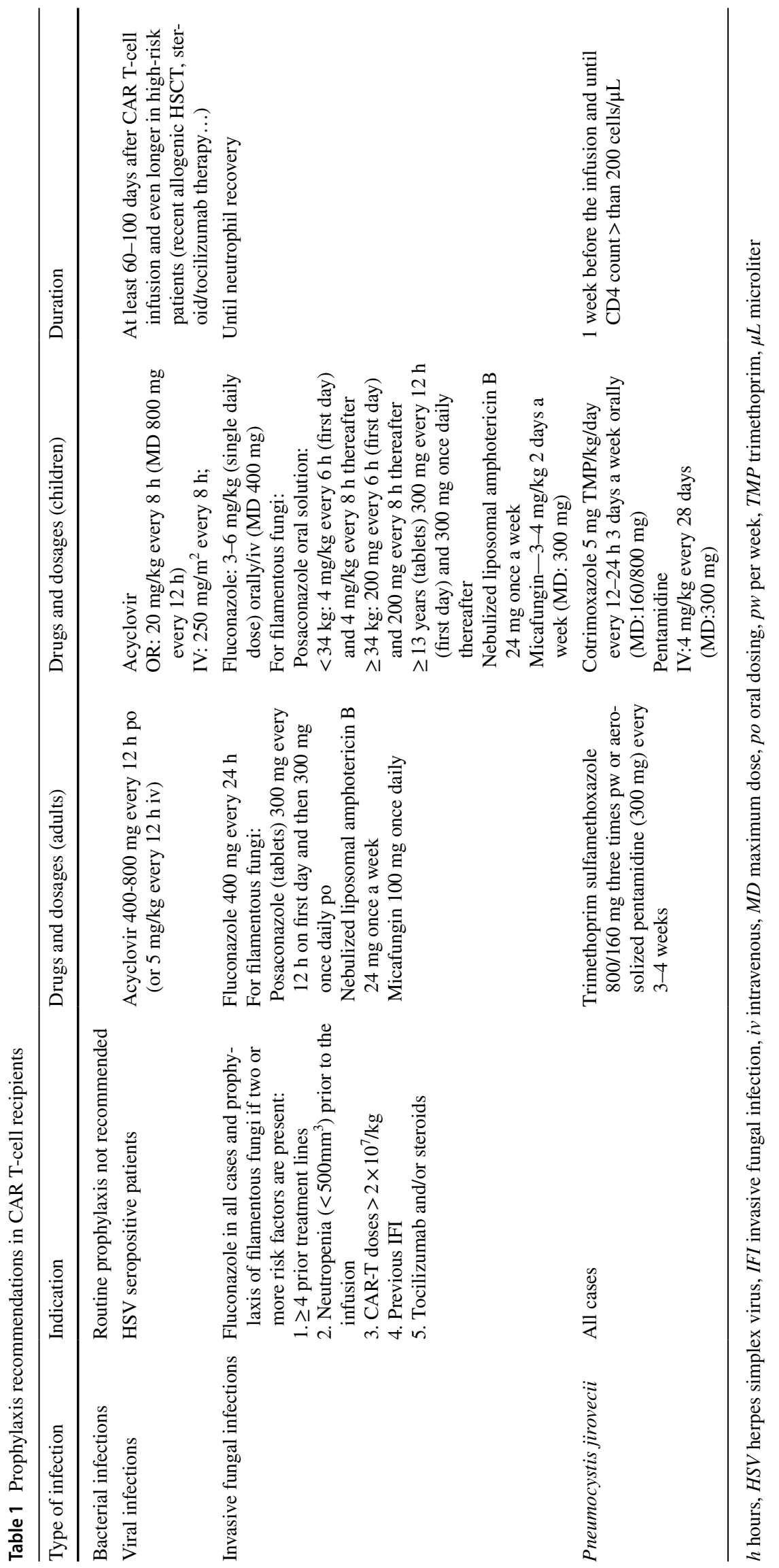


Finally, CAR T therapy causes a variable-length B-cell aplasia (while circulating CAR T persists, which varies from a few days to several years) $[24,25]$ and a progressive secondary hypogammaglobulinemia, exposing them to lifethreatening infections, especially in pediatric patients with ALL [26].

In summary, risk factors for bacterial, fungal, and viral infections are neutropenia, B-cell aplasia/hypogammaglobulinemia and impaired cellular immunity, along with the use of tocilizumab and/or corticosteroids for the treatment of CRS and/or neurotoxicity (Fig. 1) [7, 15, 26].

\section{Hypogammaglobulinemia}

In the B-cell ALL setting, a study with 43 pediatric patients and young adults showed a $90 \%$ prolonged B-cell aplasia after therapy [27].

In the ELIANA trial, all the patients who responded developed B-cell aplasia and most of them received replacement therapy with immunoglobulins according to the local policy. The median recovery time had not yet been reached, with a probability of $83 \%$ of maintaining B-cell aplasia at 6 months after infusion [18]. A single-center study, conducted at the University of Pennsylvania including 28 patients, monitored the levels of immunoglobulins after CAR T-cell therapy in 12 ALL patients. Two of these patients received replacement treatment from 12 to 22 months after the infusion due to recurrent sinopulmonary infections. The remaining ten patients did not receive substitute treatment, and recovered $\mathrm{IgG}$ count at a median of 18 months after the infusion [28]. Seventy-five percent of the patients diagnosed with non-Hodgkin lymphoma included in the ZUMA-1 [10] trial achieving disease response after axi-cel showed restored B-lymphocyte count 24 months after the infusion, and recovery began in some cases at 9 months. Thirty-three (31\%) of the 108 infused patients received replacement therapy with
Ig, including 17 (44\%) of the 39 patients with longer lasting responses [10, 29].

In conclusion, the incidence and severity of hypogammaglobulinemia varies across studies, being higher in patients with ALL. Furthermore, a recent study confirmed the persistence of circulating CD19 negative plasma cells in a small series of patients with ALL and chronic lymphocytic leukemia (CLL); the humoral response in this case could be long-lasting despite treatment with CAR T [30].

\section{Management of hypogammaglobulinemia}

Although there are some published recommendations [25, 31 , there is no clear consensus on immunoglobulin replacement therapy in patients who have received CAR T-cell therapy. The subset of patients, timepoints and schedule are the most frequently unresolved questions. Therefore, our recommendations are based on clinical experience from other neoplastic diseases (such as CLL or multiple myeloma) and hematopoietic stem cell transplantation (HSCT). In children, especially when they are under 10 years of age, the protocols of agammaglobulinemia are recommended [32].

\section{Recommendations in the adult population}

1. Monitoring

All patients should have a baseline assessment of lymphocyte subsets and immunoglobulin levels prior to lymphodepleting chemotherapy. After the infusion, the time points for assessment of lymphocyte subsets (CD4+) and immunoglobulins should be monitored:

- Monthly until the 6th month after infusion.

- After the first 6 months, it will be done according to clinical criteria. In general, among those patients without hypogammaglobulinemia, immunoglobulin levels should be assessed at least twice a year (and immunoglobulin subclasses monitored annually).

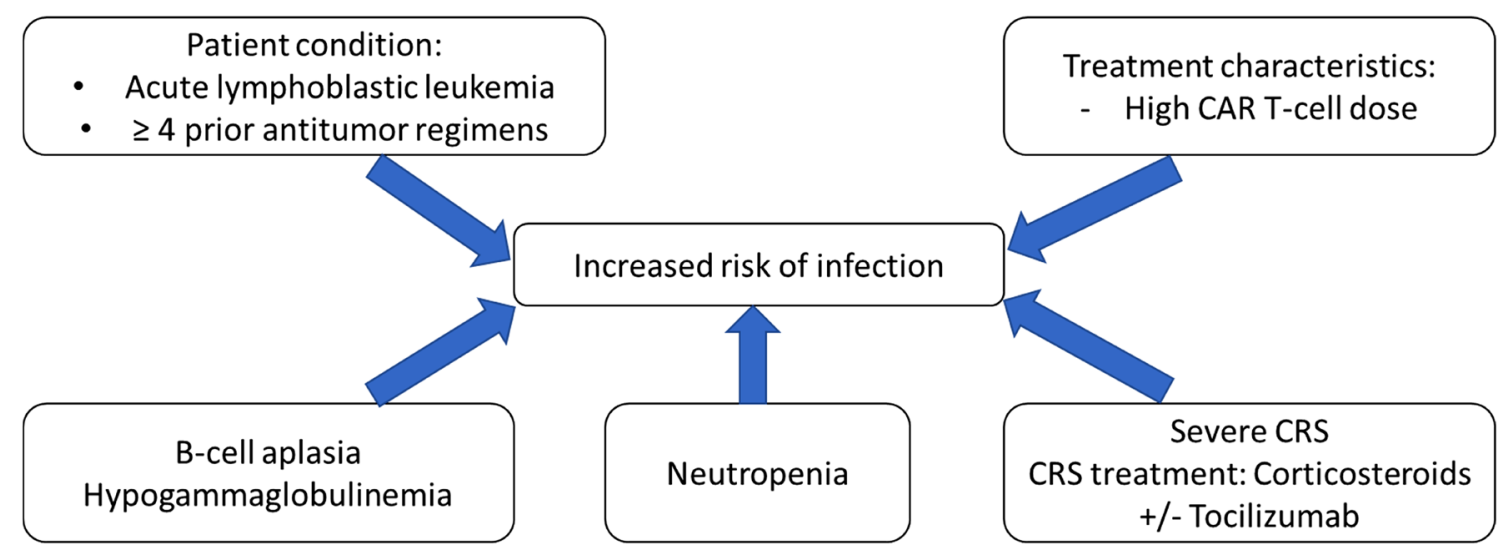

Fig. 1 Risk factors for infection in patients receiving CAR T cells 
2. Replacement therapy

- An individual IgG level has been proposed, which should be adapted to each patient over time, being the one that improves their clinical status and reduces the percentage of infections [33].

- Substitution therapy should be considered in two other situations:

o Deficit of some immunoglobulin subclass.

o Absence of seroconversion after vaccination of tetanus, diphtheria or pneumococcus.

- In overweight patients $\left(\mathrm{BMI} \geq 30 \mathrm{~kg} / \mathrm{m}^{2}\right.$ or if real weight $>20 \%$ of the ideal weight), the dose should be adjusted to the ideal adjusted weight according to the following formula: ideal adjusted weight $=$ ideal weight +0.4 [real weight $(\mathrm{kg})-$ ideal weight]

- If the patient has a selective IgA deficit, even though adverse events due to specific anti-IgA are less frequent than previously thought [34], priority should be given to products with the lowest possible amount of IgA or to subcutaneous administration [35].

- If substitution is necessary, 400-600 mg/kg every 3-4 weeks [36] is accepted as the starting dose, aiming to reach an IgG trough above $400 \mathrm{mg} / \mathrm{dL}$ in adults.

- If a patient develops frequent respiratory infections, despite monthly replacements, the physician should consider raising the dose, reducing the administration interval or switching to subcutaneous formulations.

\section{Recommendations in pediatric population}

- Replacement therapy should start $~ 1$ month after CAR $\mathrm{T}$ infusion in all patients $[24,25]$.

- The recommended replacement dose is $0.5 \mathrm{~g} / \mathrm{kg} /$ monthly [25, 37, 38], aiming to reach the normal range for the child's age.

- In children, it may be advisable to achieve higher IgG trough values (800 mg/dL) [38], especially under 10 years of age and when there are associated risk factors such as baseline pulmonary pathology, history of total body irradiation or added immunosuppression by chronic graft versus host disease.

- Replacement therapy should last as long as B-cell aplasia. If there is a persistent low $\operatorname{IgA}$ or $\operatorname{IgM}$ value replacement therapy should be maintained.

- Once there is B-cell recovery, the decision to stop immunoglobulin replacement should be evaluated on a case-by-case basis.

\section{Bacterial infections}

The incidence of bacterial infection described in patients receiving CAR T therapy ranges from 10 to $43 \%[7,15,18$, 39]. This incidence is possibly higher taking into account that some bacterial infections could be underdiagnosed in the context of CRS. Incidence of grade 4 and 5 bacterial infections $<6 \%[7,18,40]$.

\section{Prevention/prophylaxis and management of bacterial infection}

Our general recommendations for the prevention of bacterial infection in these patients are:

- Patients with an active, uncontrolled infection should not start treatment with CAR T therapy until the infection has resolved. This includes both the lymphodepleting chemotherapy and the CAR T-cell infusion.

- Antibacterial prophylaxis is not recommended.

- If the patient develops fever or infectious symptoms, even if CRS is suspected, microbiological samples should be collected and empiric antibiotic treatment initiated according to the local protocol. The empiric antibiotic therapy should take into account the individual risk of the patient and the local antibiotic resistance profile, always including Pseudomonas aeruginosa.

- The clinical situation should be reassessed $48 \mathrm{~h}$ after the onset of fever. If there is no sign of active infection, the cultures are negative, the diagnosis of CRS is highly probable and the patient is afebrile or stable, the withdrawal of the antibiotic should be considered.

- There are no differences regarding prophylaxis and treatment in the pediatric population.

\section{Viral infections}

\section{Herpesviridae}

\section{Incidence and available evidence}

Herpes simplex virus (HSV) and VZV In European countries, the seroprevalence of HSV type 1 is around $80 \%$ in adults [41]. Hence, reactivation after immunosuppressive therapy in hematological patients is very frequent in the absence of prophylaxis.

There are no specific data on the incidence of complications associated with HSV after treatment with CAR T. 
It should be noted, however, that most patients received prophylaxis with acyclovir or valacyclovir [7].

Regarding varicella zoster virus (VZV) infection, its incidence in CAR T recipients is also unknown. Patients receiving other immunosuppressive therapies, such as allogeneic HSCT, carry a high risk of developing this infection (15-50\% after 5 years of treatment/transplantation). Noteworthy, a case of early reactivation has been described in a patient who did not receive acyclovir prophylaxis [15].

Cytomegalovirus (CMV) In western European countries the CMV-positive adult population is around 70\%. Two studies $[7,15]$ have reported the incidence of CMV infection/ disease in patients treated with CAR T. Among the 186 patients included in both studies, two presented a reactivation of the virus detected by plasma PCR and one patient had a CMV pneumonia, diagnosed between days 29 and 90 post-infusion.

There are no published data on the monitoring of viremia or the use of prophylaxis in this context.

Epstein-Barr virus (EBV) Only one study [15] including 133 adult patients receiving CAR T-cell therapy for different refractory or relapsed $\mathrm{B}$-cell malignancies described the incidence of EBV infection in this context. A single patient, who developed CRS grade 4, presented a positive PCR in both plasma and cerebrospinal fluid.

Human herpesvirus 6 (HHV-6) Its seroprevalence is very high in the general population (>95\%). At present, no study has provided data on the incidence of complications related to HHV-6 in this context.

\section{Prevention/prophylaxis and management}

- Acyclovir prophylaxis should be administered in patients with a positive baseline serology, from the start of lymphodepleting chemotherapy until a minimum of 60 to 100 days after infusion (Table 1). Our recommendation is to maintain the prophylaxis up to +100 days after infusion, and even longer in subgroups of patients considered at high risk (history of recent allogeneic transplantation, adverse events related to CAR T cells that required steroid/tocilizumab treatment...). In seronegative patients for HSV and VZV, prophylaxis is not necessary. When the serological status is unknown, prophylaxis should be used routinely.

- The monitoring of CMV and EBV DNAemia should only be carried out for academic purposes, the results should not determine the start of preemptive treatment. Similarly, prevention strategies, such as letermovir or rituximab, do not seem justifiable at the present time.
- Neither directed prophylaxis nor routine monitoring of HHV-6 PCR seems to have any role in these patients.

- In the pediatric population who has previously undergone an HSCT, the recommendation is to monitor CMV, adenovirus, EBV and HHV-6 once or twice a week. If there is a positive CMV PCR result, treatment with ganciclovir or foscarnet should be initiated.

\section{Hepatotropic viruses}

Patients receiving B-cell-targeted therapy like rituximab are at a higher risk for hepatotropic viral reactivation [42]. Safety of CAR T-cell therapy in patients with chronic hepatitis B virus (HBV) or hepatitis $\mathrm{C}$ virus (HCV) infection is scarce, since most of the trials excluded patients with active, latent or past infections. A few cases of patients with very low or undetectable HBV and HCV viral load were successfully treated with CAR T cells [43]. However, a fatal case of VHB reactivation was described in a patient carrying HBsAg who discontinued antiviral prophylaxis [44].

Screening for HBV, including HBV surface antigen (HBsAg), core antibody (anti-HBc) and surface antigen antibody (anti-HBs), together with HCV and HIV is mandatory. If a patient is HBsAg positive or HBsAg negative but anti-HBc positive, an HBV DNA study should be performed, irrespective of anti-HBs [45-48]. Antiviral treatment with entecavir is recommended in HBsAg-positive patients or patients with detectable HBV DNA before starting CAR T cells and during at least 6-12 months after infusion [49-51]. The duration should be decided on a case-by-case basis. In anti-HBc positive patients, with negative $\mathrm{HBsAg}$ and $\mathrm{HBV}$ DNA, antiviral treatment or monitoring of HBV DNA every 1-3 months can be performed [50]. Patients with hepatitis $C$ infection should be considered for antiviral treatment taking into account the patient's liver function and clinical situation [52].

It is also advisable to perform a hepatitis A screening, even though there are no specific data in this context. Regarding HDV, patients with anti-HBc antibodies should be screened with anti-HDV serology, and HDV RNA should be performed if antibodies are positive [49]. HEV virus is an enteric transmitted infection usually subclinical and self-limited. However, chronic disease has been reported in immunocompromised patients and treatment with ribavirin has been suggested in this setting [49]. If a patient experiences acute liver test abnormalities during CAR T therapy, hepatotropic virus should be analyzed.

\section{Human immunodeficiency virus (HIV)}

Patients diagnosed with HIV infection were excluded from clinical trials [53], so data in this setting is scarce. The European Society for Blood and Marrow Transplantation 
(EBMT) and the Joint Accreditation Committee of ISCT and EBMT (JACIE) practice recommendations have suggested that pharmaceutical companies could manufacture CAR T cells for HIV-positive patients if the viral load was undetectable after anti-retroviral treatment [54]. The published clinical experience is limited to three patients with HIV successfully treated with CAR T cells without additional toxicity $[55,56]$.

More data are needed to make specific recommendations in this setting. Currently, the decision to treat HIV patients should be assessed on a case-by-case basis taking into account the viral load and risk of opportunistic infections.

\section{Community-acquired respiratory viruses (CRV)}

Infections of the upper and/or lower respiratory tract (URTI/ LRTI) by community respiratory viruses are one of the leading causes of morbidity and mortality worldwide with multiple direct and indirect deleterious effects, representing a huge economic burden for the health system [57]. Most viruses, including influenza, parainfluenza (PIV) and metapneumovirus (hMPV) have a seasonal predominance, from late autumn to mid spring. The PIV peaks in autumn and spring but is also frequent throughout the year.

The severity depends on the type of virus, the age of the patient, the previous immunosuppression and whether it is a primary infection or reinfection. The infections produced by these viruses are clinically indistinguishable from each other. Often, those produced by hMPV are presented in the form of co-infection with bacteria, fungi, and other CRVs, as well as CMV. These co-infections have a high mortality rate $[58,59]$.

A recently published risk scale developed in the setting of allo-HSCT recipients identified three separate risk groups (low, intermediate and high) with an increasing risk of progression to lower respiratory tract and mortality [60] Even though this risk scale, known as the "immunodeficiency score index" (ISI), was designed to predict these complications in patients with respiratory syncytial virus (RSV) infection, it has proven useful in other types such as influenza, coronavirus and adenovirus [61-63]. The variables included in ISI are neutropenia $\left(<500 / \mathrm{mm}^{3}\right)$, lymphopenia $\left(<200 / \mathrm{mm}^{3}\right)$, age $>40$ years, graft versus host disease, steroid use, myeloablative chemotherapy, and allo-HSCT. However, this scale has not been validated in patients receiving CAR T-cells.

The incidence of CRV infections after anti-CD19 CAR T therapy in two studies $[7,15]$ was around $6 \%$ within the first 30 days, and rose to $28 \%$ within the first 6 months after infusion [7]. Several studies, carried out in other high-risk populations with increased risk, showed that the presence of hypogammaglobulinemia was associated with an increased risk of mortality due to $\mathrm{CRV}[64,65]$.
The European Conference on Infections in Leukemia (ECIL) proposed some definitions based on the symptoms and PCR results to improve management strategies [66].

\section{General prevention/prophylaxis and management of respiratory virus infection}

- We recommend testing only patients with symptoms of URTI/LRTI, especially looking for the ones which have an antiviral treatment (influenza, RSV, \pm PIV and hMPV). To avoid a delay in diagnosis and treatment, rapid detection techniques for influenza and RSV antigens are a choice during the period of circulation of these viruses. However, given their lower sensitivity and specificity, multiplex PCR techniques in the same sample are advisable if rapid detection is negative.

- General precautions for preventing the transmission of CRV, including hand washing, personal protective equipment (gloves, gown and mask), and education to caregivers and patients should also be implemented in the CAR T setting. Health-care personnel and caregivers with symptoms of respiratory infection should avoid close contact with CAR T recipients.

\section{Recommendations for influenza virus}

- Influenza vaccination of CAR T recipients and close family is recommended.

- Patients with confirmed influenza before the start of CAR $T$ therapy should receive antiviral treatment and delay start of lymphodepleting chemotherapy at least 2 weeks or until resolution of symptoms.

- All patients with confirmed or probable influenza after CAR T infusion should receive treatment, regardless of the time elapsed since the infusion.

- The first-line treatment for influenza is oseltamivir. In severe cases of influenza, when the intestinal absorption of the drug is decreased (mucositis and/or diarrhea) and inhalation of zanamivir is not possible, intravenous peramivir or zanamivir could be alternatives.

- In patients with persistent symptoms, after ruling out oseltamivir resistance, treatment and isolation should be maintained until symptoms are resolved and/or PCR is negative.

\section{Recommendations for respiratory syncytial virus (RSV)}

- In patients with respiratory symptoms and a proven RSV infection before the start of CAR T therapy, it is advisable to start antiviral treatment and delay the start of lymphodepleting chemotherapy at least 2 weeks or until symptoms resolve. 
- In patients with LRTI who have received CAR T therapy within the previous 90 day and who present lymphopenia, neutropenia or hypogammaglobulinemia, ribavirin is recommended, orally or intravenously, in increasing doses up to a maximum of $30 \mathrm{mg} / \mathrm{kg} /$ day divided in three doses \pm IVIG.

- Children under 2 years of age, especially those with a history of respiratory pathology, prophylaxis with monoclonal antibodies against RSV could be considered.

\section{Recommendations for other CRV}

- In the absence of effective agents against VPI [67-69] and hMPV $[58,59]$ treatment with ribavirin \pm IVIG is advised in patients with one or more risk factors for progression to LTRI and in patients with UTRI. The possible toxicities of ribavirin, especially myelotoxicity, should be taken into account.

- There are currently no effective antiviral drugs available for enterovirus, rhinovirus, coronavirus and bocavirus. Therefore, recommendations in this setting are limited. Early identification and supportive treatment are important, together with treatment of associated bacterial and/ or fungal infections.

\section{Severe acute respiratory syndrome coronavirus 2 (SARS-CoV-2)}

In December 2019, a new virus named SARS-CoV-2 was identified in Wuhan, China [70]. The World Health Organization declared the SARS-CoV-2 outbreak a pandemic and reported on June 1, 2020 more than six million cases with 371,166 deaths [71]. Three stages of the disease have been described: an early mild infection, followed by pulmonary damage and finally a systemic hyperinflammation [72]. High levels of pro-inflammatory cytokines and biomarkers including IL-2, IL-6, IL-7, tumor necrosis- $\alpha$ or d-dimer have been identified in patients with more severe disease. For this reason, some immunomodulatory agents including tocilizumab have been investigated as possible treatment for this disease [72].

Hematological patients with SARS-CoV-2 seem to harbor a dismal outcome [73-75]. Data about SARS-CoV-2 infection in patients receiving CAR T cells are very limited [73] and do not allow drawing definitive conclusions.

Several antiviral and immunomodulatory agents are currently under evaluation for the treatment of this infection [76, 77]. In patients with oxygen saturation lower than $95 \%$, dexamethasone for 10 days as well as remdesivir for 5 days is recommended in the last Infectious Disease Society of America (IDSA) guidelines [78]. Despite the lack of data in patients receiving CAR-T cells, it seems reasonable to take a similar approach in patients developing severe SARS-CoV-2.

During the SARS-CoV-2 pandemic, health-care systems suffered a high incidence of admissions due to this disease with overuse of intensive care units (ICU) in some cases. In this context, patient selection should be conducted carefully, while still allowing patients with good performance status and limited comorbidities to be considered for CAR T-cell therapy [79].

CAR T-cell treatment candidates should follow preventive measures such as strict hygiene procedures and social distancing [77, 79]. Moreover, symptoms of SARS$\mathrm{CoV}-2$ infection should be assessed and screening of this infection with PCR should be made at relevant time points regardless of symptoms, including before apheresis, lymphodepleting chemotherapy and CAR T-cell infusion in all CAR-T cell candidates [79].

\section{Other viruses}

\section{Adenovirus (HAdV)}

There are no studies on the incidence of HAdV in patients treated with chemo-immunotherapy; however, it can cause serious problems in this population. It usually affects children or young adults. In vivo or ex vivo T-cell depletion is the main risk factor for infection in this population [80, 81 ] and severe lymphopenia $\left(<200 / \mathrm{mm}^{3}\right)$ is the main risk factor for mortality [66].

\section{Recommendations for HAdV}

- PCR monitoring is not routinely recommended in adults. In the pediatric population, it should be carried out one to two times per week. Early antiviral therapy with ribavirin is not recommended. Consider treatment with cidofovir in children, to avoid systemic disease $[82,83]$. Brincidofovir is an alternative, but currently as a compassionate use and with possible adverse events such as gastrointestinal toxicity [84].

- In patients with URTI due to hAdV, measures such as isolation, close monitoring, and assessment of risk factors for progression to LTRI are recommended. In patients with severe LTRI and at least one risk factor, antiviral treatment with cidofovir for 2-3 weeks should be considered; thereafter, every 2 weeks until complete resolution. On the day of administration of cidofovir, remember to add hydration and oral probenecid. The use of brincidofovir is restricted to intolerance/toxicity to cidofovir [83]. 


\section{Polyomavirus (Polyomavirus hominis 1 and 2)}

About $80 \%$ of the adult population is seropositive against the Polyomaviridae virus, including both pathogenic species: Polyomavirus BK (hemorrhagic cystitis) and Polyomavirus JC (progressive multifocal leukoencephalopathy). Anecdotal cases of BK infections and hemorrhagic cystitis have been described after CAR T-cell therapy [7, 15].

Taking into account the lack of conclusive data on the impact of reactivation, this possibility should always be suspected in case of the appearance of hemorrhagic cystitis (BK) or atypical neurological symptoms with a multifocal demyelination, especially when its presentation is late (JC).

Routine PCR monitoring in blood and/or urine for BK virus does not seem necessary in these patients.

\section{Fungal infections}

The incidence of invasive fungal infections (IFI) in adult patients with B-cell ALL, non-Hodgkin B-cell lymphoma or CLL treated with CAR $\mathrm{T}$ is globally between 5 and $10 \%[7,85]$. In a study including 133 patients with several hematological malignancies receiving CAR T-cells, six of them $(4.5 \%)$ developed eight episodes of IFI (5 for nonfilamentous fungi and 3 for filamentous) mostly within the first 28 days after infusion [15]. In this study, the prophylaxis consisted of fluconazole $400 \mathrm{mg} /$ day when neutrophil count was below $500 / \mathrm{mm}^{3}$. There were no deaths associated with IFI.

Four of the 53 adult patients (7.5\%) with B-cell ALL treated at MSKCC developed an IFI in the first 30 days after CAR T-cell infusion (1 yeast and 3 filamentous fungi lung infections [2 probable aspergillosis and 1 confirmed mucormycosis]). Of note, $79 \%$ of these patients received prophylaxis with micafungin at a dose of $100 \mathrm{mg} /$ day [7]. The median number of days until IFI was 23. After day 30, 1 IFI per filamentous fungus was documented. There were no deaths associated with IFI in this study.

Recently, the University of Pittsburg documented an incidence of 3\% (2/59) of IFI in their CAR T-cell recipients [86]. In the study of late complications by Cordeiro et al., [13], four fungal infections were recorded (2 Aspergillus spp., 1 Candida spp. and 1 coccidioidomycosis).

Pre-test infection prevalence is a key factor when performing diagnostic tests, including the determination of serum galactomannan (GM) and bronchoalveolar lavage (BAL) for detection of invasive aspergillosis (IA) [87]. The use of effective antifungal prophylaxis in high-risk hematologic patients has shown to successfully reduce the incidence of IA [88]. Asymptomatic monitoring twice a week based on the determination of serum GM is unreliable, since the pretest probability of infection is very low and the possibility of false positive results due to other treatments is high (intravenous antibiotic treatment, platelet transfusion, nutritional supplements). The low rate of positive test prediction in this context limits its clinical utility and may involve unnecessary diagnostic and therapeutic efforts [89, 90]. It is important to analyze each case individually to establish the risk of IFI and implement early diagnostic measures.

In a survey of 52 pediatric and adult centers in the USA, $87 \%$ administered antifungal prophylaxis to patients undergoing treatment with CAR T, the vast majority of them only against yeasts ( $92 \%$ with fluconazole). The duration of this prophylaxis was variable, but in most cases it was stopped at the time of neutrophil recovery [91]. Regarding Pneumocystis jirovecii, all centers confirmed the use of prophylaxis, mostly with cotrimoxazole.

\section{Prevention/prophylaxis and management of IFIs}

- Routine serum GM monitoring is not recommended.

- Fluconazole $400 \mathrm{mg} / 24 \mathrm{~h}$ is advisable in the neutropenic phase after lymphodepleting chemotherapy.

- If the patient presents at least two of the following high risk factors, it is recommended to perform prophylaxis of filamentous fungi until neutrophil recovery $\left(>500 / \mathrm{mm}^{3}\right)$ :

o Four or more prior treatment lines [15].

o Neutropenia below $500 / \mathrm{mm}^{3}$ prior to infusion of CAR T.

o Dose of CAR T lymphocytes greater than $2 \times 10^{7} / \mathrm{kg}$ $[7,15]$.

o Previous IFI.

o Administration of tocilizumab and/or steroids.

Prophylaxis can be carried out with posaconazole (tablets), nebulized liposomal amphotericin B or micafungin (Table 1). The duration of prophylaxis after neutrophil recovery should be decided on a case-by-case basis, taking into account the additional risk factors. Generally, we recommend 1 month of antifungal prophylaxis after tocilizumab and/or steroids.

- There are no specific data in the pediatric population, but antifungal prophylaxis is widely recommended [3] in this setting with the appropriate dose adjustments (Table 1).

- Prophylaxis against Pneumocystis jirovecii is mandatory and includes trimethoprim sulfamethoxazole or inhaled pentamidine every 3-4 weeks. Trimethoprim sulfamethoxazole should be started 1 week before the cell infusion and maintained until the CD4+ count is greater than 200 $\mathrm{cel} / \mathrm{mcL}$ (stop during admission and restart once the cytopenias have recovered). Consider pentamidine in cases at risk of increasing the period of neutropenia (Table 1). 


\section{Latent infections}

Patients receiving immunosuppressive therapy should be screened for latent infections; with CAR T-cell therapy we take a similar approach. Patients coming from or often traveling to endemic countries should be screened accordingly [92]. Specific recommendations are summarized in Table 2.

\section{Vaccination of patients receiving CAR T}

At present, there are no recommendations regarding the vaccine requirements of adult and pediatric patients treated with CAR T [93] therapy. There are no data on immunogenicity, efficacy, or safety of vaccine administration in this setting. The clinical and immunological status of these patients precludes the use of live and attenuated vaccines [94, 95].

As some patients treated with CAR T may have undergone HSCT (particularly patients with ALL) and may have not been vaccinated after this procedure, the model of vaccination after CAR T generally follows allo-HSCT vaccination schedules: the administration of vaccines is not recommended until 3 months (in the case of inactivated vaccines) or 24 months (in the case of attenuated vaccines, only if no immunosuppression is active) after cell infusion [95]. It should be noted that during B-cell aplasia and administration of polyvalent immunoglobulin replacement therapy primary responses to vaccines may be very limited. Some memory is preserved for vaccines received pre-treatment, at the expense of long-lived plasma $[30,96]$.

Finally, it is recommended to enhance the immunization of immediate family members and health-care professionals [94].

\section{Vaccination prior to CAR T therapy}

Inactivated vaccines, due to the potential poor response, will be postponed to the post-CAR T stage, with the exception of:

- Influenza in epidemic season.

- Anti-pneumococcal conjugate, as patients with B-cell ALL have a high risk of invasive pneumococcal infection.

- HBV, especially in susceptible patients with high risk of infection or reactivation, and in areas of high prevalence of this infection.

- All house contacts of patients should be immunized against influenza. Also those susceptible to varicella or measles should be vaccinated. In case of vaccination against rotavirus (only in those younger than 7 months), they cannot be in contact with the patient for the following 4 weeks.

\section{Vaccination after CAR T therapy}

- After CAR T therapy and during the B-cell depletion phase, live or attenuated vaccines should not be administered due to the risk of reactivation of the vaccine strain [97]. Postpone revaccination until the patients have recovered from B-cell aplasia.

- Regarding inactivated vaccines, and assessing the possible risk-benefit ratio [98], the influenza vaccine is recommended annually [93, 94], starting 30 days after CAR $\mathrm{T}$ infusion. There are no data confirming that two doses produce more immunogenicity than one.

- Specially important during B-cell aplasia, even though the effectiveness may be lower, are the pneumococcal conjugate vaccine (some patients have functional asplenia due to the previous treatments) and influenza (including family members and cohabitants) [97]. Those vaccines should be repeated once when the B-cell aplasia is recovered.

Table 2 Screening of infectious diseases according to the geographical area:

\begin{tabular}{|c|c|c|c|c|c|}
\hline & Central and South America & $\begin{array}{l}\text { Caribbean } \\
\text { Islands }\end{array}$ & $\begin{array}{l}\text { North Africa and } \\
\text { Middle-East }\end{array}$ & $\begin{array}{l}\text { Sub-Saharan } \\
\text { Africa }\end{array}$ & Asia \\
\hline $\begin{array}{l}\mathrm{HIV}, \mathrm{HBV}, \mathrm{HCV}, \mathrm{HSV}, \mathrm{CMV}, \mathrm{VZV}, \mathrm{TG} \\
\text { and TP serologies }\end{array}$ & Yes & Yes & Yes & Yes & Yes \\
\hline IGRA & Yes & Yes & Yes & Yes & Yes \\
\hline Parasites in feces & Yes & Yes & Yes & Yes & Yes \\
\hline Strongyloides stercolaris serology & Yes & Yes & Yes & Yes & Yes \\
\hline Plasmodium spp. PCR & Amazonian region & Yes & No & Yes & Yes \\
\hline Trypanosoma cruzi serology & Yes & No & No & No & No \\
\hline Schistosoma mansoni serology & Brasil and Venezuela & Yes & No & Yes & No \\
\hline
\end{tabular}

$C M V$ cytomegalovirus, $H B V$ hepatitis B virus, $H C V$ hepatitis $\mathrm{C}$ virus, $H I V$ human immunodeficiency virus, $H S V$ herpes simplex virus, $I G R A$ interferon-gamma release assays, $V Z V$ varicella zoster virus, $T G$ Toxoplasma gondii, TP Treponema pallidum 
Table 3 Vaccine program after CAR T-cell therapy in pediatric or adult patients with a previous HSCT

\begin{tabular}{|c|c|c|c|}
\hline Antigens (vaccines) & Time after HSCT & $\begin{array}{l}\text { Recommended interval between } \\
\text { doses }\end{array}$ & Number of doses \\
\hline $\begin{array}{l}\text { Diphteria, tetanus and pertussis } \\
\text { (DTPa-dTpa/tD) }\end{array}$ & $\begin{array}{l}6 \text { months (dose } 1) \\
7 \text { months (dose } 2) \\
8 \text { months (dose } 3) \\
18 \text { months (dose } 4)\end{array}$ & $1-2$ months & 4 \\
\hline Poliomielitis (PI) & $\begin{array}{l}6 \text { months (dose } 1) \\
7 \text { months (dose } 2) \\
8 \text { months (dose } 3) \\
18 \text { months (dose } 4)\end{array}$ & 1 month & 4 \\
\hline Haemophilus influenza $\mathrm{b}$ (Hib) & $\begin{array}{l}6 \text { months (dose } 1) \\
7 \text { months (dose } 2) \\
8 \text { months (dose } 3) \\
18 \text { months }(\text { dose } 4)\end{array}$ & 1 month & 4 \\
\hline Hepatitis B (HB) & $\begin{array}{l}6 \text { months (dose } 1) \\
7 \text { months (dose } 2) \\
8 \text { months (dose } 3) \\
18 \text { months (dose } 4)\end{array}$ & $1-2$ months & 4 \\
\hline Meningococcus (MACWY) (MB) & $\begin{array}{l}12 \text { months (dose } 1 \text { ) } \\
18 \text { months (dose } 2)\end{array}$ & 12 months (12 and 18 months) & 2 \\
\hline \multirow[t]{2}{*}{ Pneumococcus (PN13) } & Sequential schedule: & & \\
\hline & $\begin{array}{l}\text { PN13: } \\
3 \text { months (dose 1) } \\
4 \text { months (dose } 2) \\
5 \text { months (dose } 3)\end{array}$ & $1-2$ months & $\begin{array}{l}3 \\
1\end{array}$ \\
\hline (PN23) & $\begin{array}{l}\text { PN23: } \\
\text { 12-24 months (dose } 1) \\
5 \text { years after first dose of PN23 } \\
\text { (dose } 2)\end{array}$ & 2 months after PN13 & 2 \\
\hline Hepatitis A (HA) & $\begin{array}{l}6 \text { months (dose } 1) \\
12 \text { months (dose } 2)\end{array}$ & 6 months & 2 \\
\hline Influenza & 4-6 months (influenza season) & $\begin{array}{l}1 \text { month in first time vaccination of } \\
\text { patients younger than } 9 \text { years }\end{array}$ & $\begin{array}{l}1 \text { ( } 2 \text { in first-time vaccination } \\
\text { of patients younger than } \\
9 \text { years })\end{array}$ \\
\hline Papilloma virus (HPV) & $\begin{array}{l}12 \text { months (dose } 1) \\
13-14 \text { months (dose 2) } \\
18 \text { months (dose } 3)\end{array}$ & $\begin{array}{l}1-2 \text { months (between dose } 1 \text { and 2) } \\
4 \text { months (between dose } 2 \text { and } 3 \text { ) }\end{array}$ & 3 \\
\hline $\begin{array}{l}\text { Measles, mumps and rubella } \\
\text { (MMR) }\end{array}$ & $\begin{array}{l}24 \text { months (only if no immunosu- } \\
\text { pression or graft versus host dis- } \\
\text { ease are present and cell immunity } \\
\text { is reconstituted) } \\
24 \text { months (dose } 1 \text { ) } \\
25 \text { months (dose 2) }\end{array}$ & 1 month & 2 \\
\hline Varicella (VZ) & $\begin{array}{l}24 \text { months (only if no immunosu- } \\
\text { pression or graft versus host dis- } \\
\text { ease are present and cell immunity } \\
\text { is reconstituted) } \\
24 \text { months (dose } 1 \text { ) } \\
25 \text { months (dose } 2 \text { ) }\end{array}$ & 1 month & 2 \\
\hline
\end{tabular}

$H A$ hepatitis A vaccine, $H S C T$ hematopoietic stem cell transplantation, $M A C W Y$ meningococcal $\mathrm{A}, \mathrm{C}, \mathrm{W}$ and $\mathrm{Y}$ vaccine, $M B$ meningococcal B vaccine, $M M R$ measles, mumps and rubella vaccine, $H P V$ human papillomavirus vaccine, $P N 13$ pneumococcal conjugated vaccine, $P N 23$ pneumococcal polysaccharide vaccine, $V Z$ varicella vaccine

- Immunoglobulin replacement therapy may reduce the immunogenicity of vaccines. Therefore, in case of vaccination, it should be done between 1 week and $24 \mathrm{~h}$ before the next immunoglobulin infusion.
Once B-cell aplasia is resolved, the vaccination program should be started [97]. The immune response in this scenario is unknown. As in post-HSCT patients, combined vaccines could be used to improve immunological response [99-101]. 
Table 4 Proposed calendar for post-CAR T patients who have undergone HSCT

\begin{tabular}{|c|c|c|}
\hline Visit & Vaccines & Observations \\
\hline Visit 1 & $\begin{array}{l}\text { Hexavalent }^{\mathrm{a}}(1) \\
\text { PN13 (1) } \\
\text { Influenza }^{\mathrm{b}}(1)\end{array}$ & 6 months after HSCT \\
\hline Visit 2 & $\begin{array}{l}\text { Hexavalent (2) } \\
\text { PN13 (2) }\end{array}$ & 1 month after visit 1 \\
\hline Visit 3 & $\begin{array}{l}\text { Hexavalent (3) } \\
\text { PN13 (3) } \\
\text { HA (1) }\end{array}$ & 1 month after visit 2 \\
\hline Visit 4 & $\begin{array}{l}\text { MB (1) } \\
\text { MACWY (1) } \\
\text { HPV (1) }\end{array}$ & 2 months after visit 3 and also 12 months after \\
\hline Visit 5 & $\begin{array}{l}\text { PN23 (1) } \\
\text { HPV (2) }\end{array}$ & 1 month after visit 4 \\
\hline Visit 6 & $\begin{array}{l}\text { MB (2) } \\
\text { MACWY (2) } \\
\text { HA (2) } \\
\text { HPV (3) } \\
\text { Hexavalent (4) }\end{array}$ & 6 months after visit 4 and 4 months after visit 5 \\
\hline Visit 7 & $\begin{array}{l}\text { MMR (1) } \\
\text { VZ (1) }\end{array}$ & $\begin{array}{l}24 \text { months after BMT, with no immunosuppressant therapy or } \\
\text { graft versus host disease present, and cell immunity reconsti- } \\
\text { tuted }\end{array}$ \\
\hline Visit 8 & $\begin{array}{l}\text { MMR (2) } \\
\text { VZ (2) }\end{array}$ & 2 months after visit 7 \\
\hline
\end{tabular}

All visits programmed assuming HSCT performed more than 6 months before, B-cell depletion resolved and immunoglobulin production confirmed

${ }^{a} \mathrm{HA}$ : hepatitis A vaccine; HSCT: hematopoietic stem cell transplantation; HEXAVALENT: vaccine against diphtheria, tetanus, pertussis, Haemophilus influenza b, poliovirus and hepatitis B; MACWY: meningococcal A, C, W and Y vaccine; MB; meningococcal B vaccine; MMR: measles, mumps and rubella vaccine; HPV: human papillomavirus vaccine; PN13: pneumococcal conjugated vaccine; PN23: pneumococcal polysaccharide vaccine; $\mathrm{VZ}$; varicella vaccine

${ }^{\mathrm{b}}$ Influenza vaccination (one dose) can be scheduled as soon as possible. In patients younger than 9 years old who are receiving it for the first time, two doses should be administered separated by one month
In those who have not undergone HSCT, the vaccine program should include (if not administered before the cell infusion):

- Influenza in epidemic season.

- Anti-pneumococcal sequential vaccination: one dose of conjugated vaccine, followed by one dose of polysaccharide vaccine a minimum of 8 weeks after. A second dose of polysaccharide vaccine should be administered a minimum of 5 years after the first dose.

- HBV, especially in susceptible patients with high risk of infection or reactivation, and in areas of high prevalence of this infection.

- Other inactivated vaccines may be indicated if other risk factors are present (i.e., hepatitis A vaccine in patients with chronic liver disease, Haemophilus influenzae $\mathrm{b}$ and meningococcal vaccines in asplenic patients, etc.)

In those who have undergone HSCT, the proposed vaccination schedule is prepared according to the model of HSCT patients (Tables 3, 4).
Acknowledgements Collaborators (Infection Prevention in CAR T-cells Study Group): Javier Briones Meijide (Hospital de la Santa Creu i Sant Pau, Barcelona, Spain), Julio Delgado (Hospital Clínic, Barcelona, Spain), Natalia Mendoza-Palomar (Hospital Universitari Vall d'Hebron, Barcelona, Spain), Marta Moreno Alonso (Hospital La Fé, Valencia, Spain), Susana Rives (Hospital Sant Joan de Déu, Barcelona, Spain), Patricia Muñoz (Hospital General Universitario Gregorio Marañón, Madrid, Spain).

Funding This research received no specific grant from any funding agency in the public, commercial, or not-for-profit sectors.

\section{Compliance with ethical standards}

Conflict of interest ILA declares having received travel support from Gilead, MSD and Novartis, and speaker honoraria from Pfizer, outside the submitted work. GI declares honoraria from Gilead, Novartis, Roche and Celgene. $\mathrm{CDH}$ declares having received travel grants from MSD, Gilead, Novartis Jazz Pharmaceuticals, Consultancy de Novartis and Amgen, and speaker fees from Novartis, Jazz Pharmaceuticals and Sobi. JLRO received travel grants from Novartis, Gilead and Celgene. VOM is a recipient of a research grant (FEHH), travel grants (Kite, Celgene, Novartis, Roche, Takeda \& Janssen), consultant or advisory fees (Kite, Celgene, Novartis) and honoraria (Kite). PSP reports grants, personal fees and non-financial support from Gilead, 
Pfizer, MSD and Astellas Pharma, outside the submitted work. PB declares having received honoraria from Amgen, Celgene, Gilead, Incyte, Jazz Pharmaceuticals, MSD, Novartis, Pfizer and Roche, not related with the present article. IRC declares having received honoraria from, Celgene, Gilead, MSD, Astellas, Novartis, and Pfizer outside the submitted work. The rest of the authors declare that they have no conflict of interest.

\section{References}

1. Bondanza A, Bonini C, Fehse B, Hudecek M. Cellular therapy with engineered T cells, efficacy and side effects. In: Carreras E, Dufour C, Mohty M, Kröger N, editors. The EBMT handbook. 7th ed. Berlin: Springer; 2019. p. 449-455.

2. Forman SJ, Kalos M, June CH. Adoptive T-cell therapy for malignancy in the setting of hematopoietic cell transplantation. In: Antin JH, Appelbaum FR, Forman SJ, Negrin RS, editors. Thomas' hematopoietic cell transplantion. 5th ed. Wiley-Blackwell; 2016. p. 826-35.

3. Mahadeo KM, Khazal SJ, Abdel-Azim H, Fitzgerald JC, Taraseviciute A, Bollard CM, et al. Management guidelines for paediatric patients receiving chimeric antigen receptor T cell therapy. Nat Rev Clin Oncol. 2019;16:45-63.

4. Budde LE, Zaia JA. CD19 CAR-T therapy and sepsis: dancing with the devil. Blood. 2018;131:7-8.

5. Wang Z, Han W. Biomarkers of cytokine release syndrome and neurotoxicity related to CAR-T cell therapy. Biomark Res. 2018;6:4

6. Trzeciak A, Pietropaoli AP, Kim M. Biomarkers and associated immune mechanisms for early detection and therapeutic management of sepsis. Immune Netw Korean Assoc Immunol. 2020;20:e23.

7. Park JH, Romero FA, Taur Y, Sadelain M, Brentjens RJ, Hohl TM, et al. Cytokine release syndrome grade as a predictive marker for infections in patients with relapsed or refractory B-cell acute lymphoblastic leukemia treated with chimeric antigen receptor T cells. Clin Infect Dis. 2018;67:533-40.

8. Luo H, Wang N, Huang L, Zhou X, Jin J, Li C, et al. Inflammatory signatures for quick diagnosis of life-threatening infection during the CAR T-cell therapy. J Immunother Cancer. 2019;7:271.

9. Kymriah EMA product information [Internet] [cited $2020 \mathrm{Feb}$ 12]. https://www.ema.europa.eu/en/documents/product-infor mation/kymriah-epar-product-information_en.pdf. Accessed Feb 2020.

10. Locke FL, Ghobadi A, Jacobson CA, Miklos DB, Lekakis LJ, Oluwole OO, et al. Long-term safety and activity of axicabtagene ciloleucel in refractory large B-cell lymphoma (ZUMA1): a single-arm, multicentre, phase 1-2 trial. Lancet Oncol. 2019;20:31-42.

11. Logue JM, Zucchetti E, Bachmeier CA, Krivenko GS, Larson V, Ninh D, et al. Immune reconstitution and associated infections following axicabtagene ciloleucel in relapsed or refractory large B-cell lymphoma. Haematologica. 2020 (Online ahead of print).

12. Wudhikarn K, Palomba ML, Pennisi M, Garcia-Recio M, Flynn JR, Devlin SM, et al. Infection during the first year in patients treated with CD19 CAR T cells for diffuse large B cell lymphoma. Blood Cancer J. 2020;10:79.

13. Cordeiro A, Bezerra ED, Hirayama AV, Hill JA, Wu QV, Voutsinas J, et al. Late events after treatment with CD19-targeted chimeric antigen receptor modified T cells. Biol Blood Marrow Transplant. 2020;26:26-33.
14. Nastoupil LJ, Jain MD, Feng L, Spiegel JY, Ghobadi A, Lin Y, et al. Standard-of-care axicabtagene ciloleucel for relapsed or refractory large B-cell lymphoma: results from the US lymphoma CAR T consortium. J Clin Oncol. 2020; JCO1902104.

15. Hill JA, Li D, Hay KA, Green ML, Cherian S, Chen X, et al. Infectious complications of CD19-targeted chimeric antigen receptor-modified T-cell immunotherapy. Blood. 2018;131:121-30.

16. Pasquini MC, Locke FL, Herrera AF, Siddiqi T, Ghobadi A, Komanduri KV, et al. Post-marketing use outcomes of an antiCD19 chimeric antigen receptor (CAR) T cell therapy, axicabtagene ciloleucel (Axi-Cel), for the treatment of large B cell lymphoma (LBCL) in the United States (US). Blood. 2019;134:764.

17. Yescarta EMA product information [Internet]. [cited $2020 \mathrm{Feb}$ 12]. https://www.ema.europa.eu/en/documents/product-infor mation/yescarta-epar-product-information_en.pdf. Accessed Feb 2020.

18. Maude SL, Laetsch TW, Buechner J, Rives S, Boyer M, Bittencourt $\mathrm{H}$, et al. Tisagenlecleucel in children and young adults with B-cell lymphoblastic leukemia. N Engl J Med. 2018;378:439-48.

19. Schiff MH, Kremer JM, Jahreis A, Vernon E, Isaacs JD, van Vollenhoven RF. Integrated safety in tocilizumab clinical trials. Arthritis Res Ther. 2011;13:R141.

20. Frigault MJ, Nikiforow S, Mansour MK, Hu ZH, Horowitz MM, Riches ML, et al. Tocilizumab not associated with increased infection risk after CAR T-cell therapy: implications for COVID19? Blood. 2020;136:137-9.

21. Strati P, Ahmed S, Kebriaei P, Nastoupil LJ, Claussen CM, Watson $\mathrm{G}$, et al. Clinical efficacy of anakinra to mitigate CAR T-cell therapy-associated toxicity in large B-cell lymphoma. Blood Adv. 2020;4:3123-7.

22. Salliot C, Dougados M, Gossec L. Risk of serious infections during rituximab, abatacept and anakinra treatments for rheumatoid arthritis: meta-analyses of randomised placebo-controlled trials. Ann Rheum Dis. 2009;68:25-322.

23. Winthrop KL, Mariette X, Silva JT, Benamu E, Calabrese LH, Dumusc A, et al. ESCMID Study Group for Infections in Compromised Hosts (ESGICH) Consensus Document on the safety of targeted and biological therapies: an infectious diseases perspective (soluble immune effector molecules [II]: agents targeting interleukins. Immunoglobuli Clin Microbiol Infect. 2018;21:S21-40.

24. Maude SL, Frey N, Shaw PA, Aplenc R, Barrett DM, Bunin NJ, et al. Chimeric antigen receptor $\mathrm{T}$ cells for sustained remissions in leukemia. N Engl J Med. 2014;371:1507-17.

25. Doan A, Pulsipher MA. Hypogammaglobulinemia due to CAR T-cell therapy. Pediatr Blood Cancer. 2018;65:e26914.

26. Vora SB, Waghmare A, Englund JA, Qu P, Gardner RA, Hill JA. Infectious complications following CD19 chimeric antigen receptor T-cell therapy for children, adolescents, and young adults. Open Forum Infect Dis. 2020;7:ofaa121.

27. Gardner RA, Finney O, Annesley C, Brakke H, Summers C, Leger K, et al. Intent-to-treat leukemia remission by CD19 CAR $\mathrm{T}$ cells of defined formulation and dose in children and young adults. Blood. 2017;129:3322-31.

28. Schuster SJ, Svoboda J, Chong EA, Nasta SD, Mato AR, Anak Ö, et al. Chimeric antigen receptor T cells in refractory B-cell lymphomas. N Engl J Med. 2017;377:2545-54.

29. Neelapu SS, Locke FL, Bartlett NL, Lekakis LJ, Miklos DB, Jacobson CA, et al. Axicabtagene ciloleucel CAR T-cell therapy in refractory large B-cell lymphoma. N Engl J Med. 2017;377:2531-44.

30. Bhoj VG, Arhontoulis D, Wertheim G, Capobianchi J, Callahan CA, Ellebrecht CT, et al. Persistence of long-lived plasma cells and humoral immunity in individuals responding to CD19directed CAR T-cell therapy. Blood. 2016;128:360-70. 
31. Hill JA, Giralt S, Torgerson TR, Lazarus HM. CAR-T—and a side order of IgG, to go?-Immunoglobulin replacement in patients receiving CAR-T cell therapy. Blood Rev. 2019;38:100596.

32. Kansagra AJ, Frey NV, Bar M, Laetsch TW, Carpenter PA, Savani BN, et al. Clinical utilization of chimeric antigen receptor T-cells (CAR-T) in B-cell acute lymphoblastic leukemia (ALL) - an expert opinion from the European Society for Blood and Marrow Transplantation (EBMT) and the American Society for Blood and Marrow Transplant. Bone Marrow Transplant. 2019;54:1868-80.

33. Bonagura VR, Marchlewski R, Cox A, Rosenthal DW. Biologic $\mathrm{IgG}$ level in primary immunodeficiency disease: the $\mathrm{IgG}$ level that protects against recurrent infection. J Allergy Clin Immunol. 2008;122:210-2.

34. Björkander J, Hammarström L, Smith CI, Buckley RH, Cunningham-Rundles C, Hanson LA. Immunoglobulin prophylaxis in patients with antibody deficiency syndromes and anti- $\operatorname{IgA}$ antibodies. J Clin Immunol. 1987;7:8-15.

35. Sundin U, Nava S, Hammarström L. Induction of unresponsiveness against IgA in IgA-deficient patients on subcutaneous immunoglobulin infusion therapy. Clin Exp Immunol. 1998;112:341-6.

36. Hernandez-Trujillo HS, Chapel H, Lo Re V, Notarangelo LD, Gathmann B, Grimbacher B, et al. Comparison of American and European practices in the management of patients with primary immunodeficiencies. Clin Exp Immunol. 2012;169:57-69.

37. Gutiérrez-Gutiérrez B, Salamanca E, de Cueto M, Hsueh P-R, Viale P, Paño-Pardo JR, et al. Effect of appropriate combination therapy on mortality of patients with bloodstream infections due to carbapenemase-producing Enterobacteriaceae (INCREMENT): a retrospective cohort study. Lancet Infect Dis. 2017;17:726-34.

38. Perez EE, Orange JS, Bonilla F, Chinen J, Chinn IK, Dorsey M, et al. Update on the use of immunoglobulin in human disease: a review of evidence. J Allergy Clin Immunol. 2017;139:S1-46.

39. Cardozo C, Delgado J, Ortiz-Maldonado V, Puerta-Alcalde P, Urbano-Ispizua A, Juan M, Esteve J, Soriano A, Garcia-Vidal C. Infections in haematological patients receiving chimeric antigen receptor T cell immunotherapy. Oral Session 00802:90 (Final progr)

40. Schuster SJ, Bishop MR, Tam CS, Waller EK, Borchmann P, McGuirk JP, et al. Tisagenlecleucel in adult relapsed or refractory diffuse large B-cell lymphoma. N Engl J Med. 2019;380:45-56.

41. Korr G, Thamm M, Czogiel I, Poethko-Mueller C, Bremer V, Jansen K. Decreasing seroprevalence of herpes simplex virus type 1 and type 2 in Germany leaves many people susceptible to genital infection: time to raise awareness and enhance control. BMC Infect Dis. 2017;17:471.

42. Shih CA, Chen WC, Yu HC, Cheng JS, Lai KH, Hsu JT, et al. Risk of severe acute exacerbation of chronic HBV infection cancer patients who underwent chemotherapy and did not receive anti-viral prophylaxis. PLoS ONE. 2015;10:e0132426.

43. Strati P, Nastoupil LJ, Fayad LE, Samaniego F, Adkins S, Neelapu SS. Safety of CAR T-cell therapy in patients with B-cell lymphoma and chronic hepatitis $\mathrm{B}$ or $\mathrm{C}$ virus infection. Blood. 2019;133:2800-2.

44. Wei J, Zhu X, Mao X, Huang L, Meng F, Zhou J. Severe early hepatitis $B$ reactivation in a patient receiving anti-CD19 and anti-CD22 CAR T cells for the treatment of diffuse large B-cell lymphoma. J Immunother cancer. 2019;7:315.

45. Reddy KR, Beavers KL, Hammond SP, Lim JK, Falck-Ytter YT, American Gastroenterological Association Institute. American Gastroenterological Association Institute guideline on the prevention and treatment of hepatitis B virus reactivation during immunosuppressive drug therapy. Gastroenterology. 2015;148:215-9 (quiz e16-7).
46. Gentile G, Andreoni M, Antonelli G, Sarmati L. Screening, monitoring, prevention, prophylaxis and therapy for hepatitis $B$ virus reactivation in patients with haematologic malignancies and patients who underwent haematologic stem cell transplantation: a systematic review. Clin Microbiol Infect. 2017;23:916-23.

47. Totani H, Kusumoto S, Ishida T, Masuda A, Yoshida T, Ito A, et al. Reactivation of hepatitis B virus (HBV) infection in adult T-cell leukemia-lymphoma patients with resolved HBV infection following systemic chemotherapy. Int J Hematol. 2015;101:398-404.

48. Seto W-K, Chan TS-Y, Hwang Y-Y, Wong DK-H, Fung J, Liu $\mathrm{KS}-\mathrm{H}$, et al. Hepatitis B reactivation in occult viral carriers undergoing hematopoietic stem cell transplantation: a prospective study. Hepatology. 2017;65:1451-61.

49. Mallet V, van Bömmel F, Doerig C, Pischke S, Hermine O, Locasciulli A, et al. Management of viral hepatitis in patients with haematological malignancy and in patients undergoing haemopoietic stem cell transplantation: recommendations of the 5th European Conference on Infections in Leukaemia (ECIL-5). Lancet Infect Dis Lancet Publish Group. 2016;16:606-17.

50. Hill JA, Seo SK. How I prevent infections in patients receiving CD19-targeted chimeric antigen receptor T cells for B-cell malignancies. Blood. 2020;136:925-35.

51. Hwang JP, Torres HA. Hepatitis B virus and hepatitis C virus infection in immunocompromised patients. Curr Opin Infect Dis NLM (Medline). 2018;31:535-41.

52. Pawlotsky J-M, Negro F, Aghemo A, Berenguer M, Dalgard O, Dusheiko G, et al. EASL recommendations on treatment of hepatitis C 2018. J Hepatol. 2018;69:461-511.

53. Hayden PJ, Sirait T, Koster L, Snowden JA, Yakoub-Agha I. An international survey on the management of patients receiving CAR T-cell therapy for haematological malignancies on behalf of the chronic malignancies working party of EBMT. Curr Res Transl Med. 2019;67:79-88.

54. Yakoub-Agha I, Chabannon C, Bader P, Basak GW, Bonig $\mathrm{H}$, Ciceri $\mathrm{F}$, et al. Management of adults and children undergoing chimeric antigen receptor T-cell therapy: best practice recommendations of the European Society for Blood and Marrow Transplantation (EBMT) and the Joint Accreditation Committee of ISCT and EBMT (JACIE). Haematologica. 2020;105:297-316.

55. Abramson JS, Irwin KE, Frigault MJ, Dietrich J, McGree B, Jordan JT, et al. Successful anti-CD19 CAR T-cell therapy in HIVinfected patients with refractory high-grade B-cell lymphoma. Cancer. 2019;125:3692-8.

56. Abbasi A, Peeke S, Shah N, Mustafa J, Khatun F, Lombardo A, et al. Axicabtagene ciloleucel CD19 CAR-T cell therapy results in high rates of systemic and neurologic remissions in ten patients with refractory large B cell lymphoma including two with HIV and viral hepatitis. J Hematol Oncol. 2020;13:1.

57. WHO [Internet]. 2017 [cited 2017 Aug 28]. https://www.who. int/en. Accessed Feb 2020.

58. Williams JV, Martino R, Rabella N, Otegui M, Parody R, Heck $\mathrm{JM}$, et al. A prospective study comparing human metapneumovirus with other respiratory viruses in adults with hematologic malignancies and respiratory tract infections. J Infect Dis. 2005;192:1061-5.

59. Debur MC, Vidal LR, Stroparo E, Nogueira MB, Almeida SM, Takahashi GA, et al. Human metapneumovirus infection in hematopoietic stem cell transplant recipients. Transpl Infect Dis. 2010;12:173-9.

60. Shah DP, Ghantoji SS, Ariza-Heredia EJ, Shah JN, El Taoum $\mathrm{KK}$, Shah PK, et al. Immunodeficiency scoring index to predict poor outcomes in hematopoietic cell transplant recipients with RSV infections. Blood. 2014;123:3263-8. 
61. Pinaña JL, Perez A, Montoro J, Gimenez E, Gómez MD, Lorenzo I, et al. Clinical effectiveness of influenza vaccination after allogeneic hematopoietic stem cell transplantation: a cross-sectional, prospective. Obser Study Clin Infect Dis. 2019;68:1894-903.

62. Kmeid J, Vanichanan J, Shah DP, El Chaer F, Azzi J, Ariza-Heredia EJ, et al. Outcomes of influenza infections in hematopoietic cell transplant recipients: application of an immunodeficiency scoring index. Biol Blood Marrow Transplant. 2016;22:542-8.

63. Wang L, Allen J, Diong C, Goh YT, Gopalakrishnan S, Ho A, et al. Respiratory virus infection after allogeneic hematopoietic stem cell transplant in a tropical center: predictive value of the immunodeficiency scoring index. Transpl Infect Dis. 2017; 19:e12693.

64. Spahr Y, Tschudin-Sutter S, Baettig V, Compagno F, Tamm M, Halter J, et al. Community-acquired respiratory paramyxovirus infection after allogeneic hematopoietic cell transplantation: a single-center experience. Open Forum Infect Dis. 2018;5:ofy077.

65. Khanna N, Steffen I, Studt JD, Schreiber A, Lehmann T, Weisser M, et al. Outcome of influenza infections in outpatients after allogeneic hematopoietic stem cell transplantation. Transpl Infect Dis. 2009;11:100-5.

66. Matthes-Martin S, Feuchtinger T, Shaw PJ, Engelhard D, Hirsch $\mathrm{HH}$, Cordonnier $\mathrm{C}$, et al. European guidelines for diagnosis and treatment of adenovirus infection in leukemia and stem cell transplantation: summary of ECIL-4. Transpl Infect Dis. 2011;2012:555-63.

67. Chakrabarti S, Collingham KE, Holder K, Oyaide S, Pillay D, Milligan DW. Parainfluenza virus type 3 infections in hematopoetic stem cell transplant recipients: response to ribavirin therapy. Clin Infect Dis. 2000;31:1516-8.

68. Stankova J, Carret AS, Moore D, McCusker C, Mitchell D, Davis $\mathrm{M}$, et al. Long-term therapy with aerosolized ribavirin for parainfluenza 3 virus respiratory tract infection in an infant with severe combined immunodeficiency. Pediatr Transplant. 2007;11:209-13.

69. Sparrelid E, Ljungman P, Ekelöf-Andström E, Aschan J, Ringdén $\mathrm{O}$, Winiarski J, et al. Ribavirin therapy in bone marrow transplant recipients with viral respiratory tract infections. Bone Marrow Transplant. 1997;19:905-8.

70. Huang C, Wang Y, Li X, Ren L, Zhao J, Hu Y, et al. Clinical features of patients infected with 2019 novel coronavirus in Wuhan, China. Lancet. 2020;395:497-506.

71. Coronavirus disease 2019 (COVID-19) Situation report-133. World Health Organization [Internet]. [cited 2020 Jun 2]. https ://www.who.int/docs/default-source/coronaviruse/situationreports/20200601-covid-19-sitrep-133.pdf?sfvrsn=9a56f2ac_4. Accessed June 2020.

72. Siddiqi HK, Mehra MR. COVID-19 illness in native and immunosuppressed states: a clinical-therapeutic staging proposal. J Hear Lung Transplant. 2020;39:405-7.

73. Malard F, Genthon A, Brissot E, van de Wyngaert Z, Marjanovic Z, Ikhlef S, et al. COVID-19 outcomes in patients with hematologic disease. Bone Marrow Transplant. 2020 (online ahead of print).

74. Martín-Moro F, Marquet J, Piris M, Michael BM, Sáez AJ, Corona M, et al. Survival study of hospitalized patients with concurrent Covid-19 and haematological malignancies. Br J Haematol. 2020;190:bjh16801.

75. He W, Chen L, Chen L, Yuan G, Fang Y, Chen W, et al. COVID-19 in persons with haematological cancers. Leukemia. 2020;34:1637-45.

76. Ardura M, Hartley D, Dandoy C, Lehmann L, Jaglowski S, Auletta JJ. Addressing the impact of the coronavirus disease 2019 (COVID-19) pandemic on hematopoietic cell transplantation: learning networks as a means for sharing best practices. Biol Blood Marrow Transplant. 2020;26:e147-e160160.
77. Ljungman P, Mikulska M, de la Camara R, Basak GW, Chabannon C, Corbacioglu S, et al. The challenge of COVID-19 and hematopoietic cell transplantation; EBMT recommendations for management of hematopoietic cell transplant recipients, their donors, and patients undergoing CAR T-cell therapy. Bone Marrow Transplant. 2020. https://doi.org/10.1038/s4140 9-020-0919-0.

78. Infectious Diseases Society of America Guidelines on the Treatment and Management of Patients with COVID-19 [Internet]. [cited 2020 Aug 12]. Available from: https://www.idsociety. org/practice-guideline/covid-19-guideline-treatment-and-manag ement/. Accessed Aug 2020.

79. Bachanova V, Bishop MR, Dahi P, Dholaria B, Grupp SA, HayesLattin B, et al. Chimeric antigen receptor $\mathrm{T}$ cell therapy during the COVID-19 pandemic. Biol Blood Marrow Transplant. 2020;26:1239-46.

80. Walls T, Hawrami K, Ushiro-Lumb I, Shingadia D, Saha V, Shankar AG. Adenovirus infection after pediatric bone marrow transplantation: is treatment always necessary? Clin Infect Dis. 2005;40:1244-9.

81. Runde V, Ross S, Trenschel R, Lagemann E, Basu O, RenzingKöhler K, et al. Adenoviral infection after allogeneic stem cell transplantation (SCT): report on 130 patients from a single SCT unit involved in a prospective multi center surveillance study. Bone Marrow Transplant. 2001;28:51-7.

82. Ljungman P, de la Camara R, Robin C, Crocchiolo R, Einsele H, Hill JA, et al. Guidelines for the management of cytomegalovirus infection in patients with haematological malignancies and after stem cell transplantation from the 2017 European Conference on Infections in Leukaemia (ECIL 7). Lancet Infect Dis. 2019;19:e260-e272272.

83. Hiwarkar P, Kosulin K, Cesaro S, Mikulska M, Styczynski J, Wynn R, et al. Management of adenovirus infection in patients after haematopoietic stem cell transplantation: State-of-the-art and real-life current approach: a position statement on behalf of the infectious diseases working party of the European society of blood and marrow transplantation. Rev Med Virol. 2018;28:e1980.

84. Marty FM, Winston DJ, Chemaly RF, Mullane KM, Shore TB, Papanicolaou GA, et al. A randomized, double-blind, placebocontrolled phase 3 trial of oral brincidofovir for cytomegalovirus prophylaxis in allogeneic hematopoietic cell transplantation. Biol Blood Marrow Transplant. 2019;25:369-81.

85. Hill JB, Sheffield JS, McIntire DD, Wendel GD. Acute pyelonephritis in pregnancy. Obstet Gynecol. 2005;105:18-23.

86. Haidar G, Dorritie K, Farah R, Bogdanovich T, Nguyen MH, Samanta P. Invasive mold infections after chimeric antigen receptor-modified T-cell therapy: a case series, review of the literature, and implications for prophylaxis. Clin Infect Dis. 2019;71:672-6.

87. Donnelly JP, Leeflang MM. Galactomannan detection and diagnosis of invasive Aspergillosis. Clin Infect Dis. 2010;50:1070-1.

88. Cornely OA, Maertens J, Winston DJ, Perfect J, Ullmann AJ, Walsh TJ, et al. Posaconazole vs. fluconazole or itraconazole prophylaxis in patients with neutropenia. N Engl J Med. 2007;356:348-59.

89. Duarte RF, Sánchez-Ortega I, Cuesta I, Arnan M, Patiño B, Fernández de Sevilla A, et al. Serum galactomannan-based early detection of invasive aspergillosis in hematology patients receiving effective antimold prophylaxis. Clin Infect Dis. 2014;59:1696-702.

90. Vena A, Bouza E, Álvarez-Uría A, Gayoso J, Martín-Rabadán P, Cajuste F, et al. The misleading effect of serum galactomannan testing in high-risk haematology patients receiving prophylaxis with micafungin. Clin Microbiol Infect. 2017;23:1000.e1-.e4.

91. Mahmoudjafari Z, Hawks KG, Hsieh AA, Plesca D, Gatwood KS, Culos KA. American society for blood and marrow 
transplantation pharmacy special interest group survey on chimeric antigen receptor $\mathrm{T}$ cell therapy administrative, logistic, and toxicity management practices in the United States. Biol Blood Marrow Transplant. 2019;25:26-33.

92. Sánchez-Montalvá A, Salvador F, Ruiz-Camps I, Barba P, Valcárcel $\mathrm{D}$, Sulleiro E, et al. Imported disease screening prior to chemotherapy and bone marrow transplantation for oncohematological malignancies. Am J Trop Med Hyg. 2016;95:1463-8.

93. Buitrago J, Adkins S, Hawkins M, Iyamu K, Oort T. Adult survivorship: considerations following CAR T-cell therapy. Clin J Oncol Nurs. 2019;23:42-8.

94. Peremiquel-Trillas P, Leguízamo LM, Asensio Ostos C, Martínez-Gómez X. Vacunas para pacientes en tratamiento con fármacos inmunodepresores, inmunomoduladores o biológicos. Med Clin (Barc). 2018;151:498-502.

95. National Comprehensive Cancer Network. NCCN Clinical Practice Guidelines in Oncology (NCCN Guidelines): Prevention and treatment of cancer-related infections [v.2.2016] 2016.

96. Sánchez-Ramón S, Bermúdez A, González-Granado LI, Rodríguez-Gallego C, Sastre A, Soler-Palacín P, et al. Primary and secondary immunodeficiency diseases in oncohaematology: warning signs, diagnosis, and management. Front Immunol. 2019;10:586.

97. Documento de consenso internacional, Comité Asesor de Vacunas de la AEP. Año 2016 [Internet]. 2016. Available from: https ://vacunasaep.org/profesionales/noticias/consenso-vacunacion -situaciones-especiales. Accessed Aug 2020.

98. Chong CR, Park V, Harding JJ, Brite J, Wolchok JD, Kamboj M. Safety of influenza vaccination in patients undergoing immunotherapy treatment for advanced cancer. J Clin Oncol. 2018;36:e15073.

99. Rubin LG, Levin MJ, Ljungman P, Davies EG, Avery R, Tomblyn M, et al. Executive summary: 2013 IDSA clinical practice guideline for vaccination of the immunocompromised host. Clin Infect Dis. 2014;58:309-18.

100. Carpenter PA, Englund JA. How I vaccinate blood and marrow transplant recipients. Blood. 2016;127:2824-32.

101. Guidelines for vaccination of patients with hematological malignances and HSTC recipients. 7 European Conference on Infections in Leukaemia (ECIL), 22-23 Sep 2017, Juan-Les-Pins France.

\section{Affiliations}

\section{Ibai Los-Arcos ${ }^{1,2}$. Gloria lacoboni ${ }^{3,4} \cdot$ Manuela Aguilar-Guisado $^{5}$. Laia Alsina-Manrique ${ }^{6} \cdot$ Cristina Díaz de Heredia $^{7}$. Claudia Fortuny-Guasch ${ }^{8}$. Irene García-Cadenas ${ }^{9}$. Carolina García-Vidal ${ }^{10} \cdot$ Marta González-Vicent $^{11}$. Rafael Hernani ${ }^{12} \cdot$ Mi Kwon $^{13}$. Marina Machado ${ }^{14}$. Xavier Martínez-Gómez ${ }^{15} \cdot$ Valentín Ortiz Maldonado $^{16,17}$. Carolina Pinto $\mathrm{Pla}^{18}$. José Luis Piñana ${ }^{19} \cdot$ Virginia Pomar $^{20}$. Juan Luis Reguera-Ortega ${ }^{21}$. Miguel Salavert ${ }^{22}$. Pere Soler-Palacín ${ }^{23} \cdot$ Lourdes Vázquez-López $^{24} \cdot$ Pere Barba $^{3,4}(1) \cdot$ Isabel Ruiz-Camps ${ }^{1,2}$}

1 Infectious Diseases Department, Hospital Universitari Vall D’Hebron, Barcelona, Spain

2 Department of Medicine, Universitat Autònoma de Barcelona, Barcelona, Spain

3 Deparment of Hematology, Vall D'Hebron Institute of Oncology (VHIO), Hospital Universitari Vall D’Hebron, Barcelona, Spain

4 Department of Medicine, Universitat Autònoma de Barcelona, Passeig Vall d'Hebron 119-129, 08035 Barcelona, Spain

5 Department of Infectious Diseases, Microbiology and Preventive Medicine, University Hospital Virgen del Rocío/CSIC/Institute of Biomedicine of Seville (IBIS), Seville, Spain

6 Clinical Immunology and Primary Immunodeficiencies Unit, Hospital Sant Joan de Deu, Barcelona, Spain

7 Paediatric Oncology and Hematology Department, Hematopoietic Stem Cell Transplantation, Hospital Universitari Vall D'Hebron, Barcelona, Spain

8 Infectious Diseases Unit, Hospital Sant Joan de Deu, Barcelona, Spain

9 Hematology Department, Hospital de La Santa Creu I Sant Pau, Sant Pau and Jose Carreras Leukemia Research Institutes, Autonomous University of Barcelona, Barcelona, Spain

10 Department of Infectious Diseases, Hospital Clínic, IDIBAPS (Institut D'Investigacions biomèdiques Agust Pi I Sunyer), Universitat de Barcelona, Barcelona, Spain
11 Hematopoietic Stem Cell Transplantation and Cellular Therapy Unit, Hospital Infantil Universitario "Niño Jesus", Madrid, Spain

12 Department of Hematology, Hospital Clínico Universitario, Institute for Research INCLIVA, Valencia, Spain

13 Haematology and Haemotherapy Department, Hospital General Universitario Gregorio Marañón, Gregorio Marañón Health Research Institute, Madrid, Spain

14 Clinical Microbiology and Infectious Diseases, Hospital General Universitario Gregorio Marañón, Gregorio Marañón Health Research Institute, Madrid, Spain

15 Epidemiology Department, Vall D'Hebron University Hospital, Universitat Autònoma de Barcelona, Barcelona, Spain

16 Department of Hematology, Hospital Clínic de Barcelona, Institut D'Investigacions Biomèdiques August Pi I Sunyer (IDIBAPS), University of Barcelona, Barcelona, Spain

17 Centro de Investigación Biomédica en Red de Cáncer (CIBERONC), University of Barcelona, Barcelona, Spain

18 Infectious Diseases Unit, Hospital Clínico Universitario, Instituto de Investigación INCLIVA, Valencia, Spain

19 Hematology Division, Hospital Universitario Y politécnico $\mathrm{La} \mathrm{Fe}$, Instituto de investigación sanitaria $\mathrm{La} \mathrm{Fe}$, Valencia, CIBERONC, Instituto Carlos III, Madrid, Spain

20 Infectious Disease Unit, Internal Medicine Department, Hospital de La Santa Creu I Sant Pau, Barcelona, Spain 
21 Department of Haematology, University Hospital Virgen del Rocío/CSIC/Institute of Biomedicine of Seville (IBIS), Seville, Spain

22 Infectious Diseases Unit, Área Clínica Médica, Hospital Universitario Y Politécnico La Fe, Valencia, Spain
23 Pediatric Infectious Diseases and Immunodeficiencies Unit, Hospital, Universitari Vall D’Hebron, Barcelona, Spain

24 Department of Haematology, University Hospital of Salamanca, Salamanca, Spain 